ACTA AGROBOTANICA

Vol. 59, z. 12006

s. 355364

\title{
Comparison of pollen concentration of selected tree taxa in Lublin and in the Roztocze region (SE Poland) - the results of three monitoring methods
}

\author{
IRENA AGNIESZKA PIDEK ${ }^{1}$, \\ ELŻBIETA WERYSZKO-CHMIELEWSKA ${ }^{2}$, \\ KRYSTYNA PIOTROWSKA ${ }^{2}$
}

\author{
${ }^{1}$ Institute of the Earth Sciences, M.Curie Sklodowska University, \\ al.Krasnicka 2c/d, PL 20718 Lublin \\ ${ }^{2}$ Department of Botany, Agricultural University, Akademicka 15, PL 20950 Lublin
}

(Received: 20.11.2005)

\section{S u m m a r y}

Anemophilous trees of Betula and Alnus genera produce very high amount of easily spreading pollen. Carpinus and Fagus discharge lower amount of pollen to the atmosphere. Trees belonging to the mentioned genera occur in vegetation cover of Lublin and the Roztocze region where the comparative studies were carried out in the years 1998-2004. The objective of these studies was to determine pollen concentration of four tree taxa in these study areas located $120 \mathrm{~km}$ apart. Annual pollen sums, obtained by means of three methods, were compared in order to find similarity of alternating high and low pollen production by trees in particular years. In the Roztocze region the studies were continued during the mentioned seven years as a part of Pollen Monitoring Programme, which provides multi-annual data for the palaeoecological reconstructions of Quaternary and the interpretations of phenologic-climatic nature. Standard Tauber traps were used in the Roztocze area. In Lublin the gravimetric method was used in the years 1999-2000, and the volumetric method in the years 20012004. Similar trends were found in Lublin and in the Roztocze region as to the concentrations in the air of pollen of the mentioned four taxa in particular years of the research period. Betula and Alnus discharged the greatest amount of pollen. In 1999 the great similarity of annual pollen sums of three taxa was recorded by means of the gravimetric method in all measurement points. Fagus was an exception, as its pollen concentration was much higher in the Roztocze region than in Lublin. In the case of Carpinus the enhanced pollen concentration was 
recorded in both study areas in 2002, and the highest concentration of Fagus occurred in 2003. During several years of studies we recorded great similarity of the obtained results in two study areas far apart.

Key words: pollen monitoring, modern pollen deposition, Tauber traps, actuopalynology

\section{INTRODUCTION}

In the last years the pollen production by plants have been studied in detail not only because of the increasing incidence of pollinosis, but also due to the usefulness of these investigations for palaeoecological research and reconstruction of palaeoclimatic conditions, and also for forecasting of climate changes in the future.

Different methods are practiced in order to accomplish the above-mentioned purposes. Dynamics of pollen concentration in the air and deposition during pollen seasons is studied for the purposes of allergology and phenology with the use of volumetric method (Hirst, 1952; Raynor, 1979; Käpylä \& Penttinen, 1981), and more and more rarely the gravimetric method (D u r h a m, 1964; M a n drioli et al., 1998).

Standard Tauber traps, basing also on gravimetric method ( $\mathrm{Hicks}$ et al., 1996), are used in the studies aimed at palaeoecological reconstructions of the Quaternary. These studies are part of the international project Pollen Monitoring Programme (PMP), which is coordinated by the University of Oulu, Finland. The purpose of the PMP project is to count pollen deposition of different taxa of trees and other plants in the conditions similar to the natural ones (national parks, reserves) allowing rather objective interpretation of the features of local and regional vegetation and phenologic-climatic changes (H i c k s et al., 1996; B r o s trö m, 2002).

Anemophilous trees discharge to the atmosphere very high amount of easily spreading pollen. The variability of pollen concentration in a specified volume of the air, recorded in particular years, is conditioned by biological and climatic factors (L a ta $\nmid$ ow a et al., 2002; S pieksma et al., 2003).

In the studies, which were continued during seven years, there were compared the annual pollen sums of four taxa, i.e. Alnus, Betula, Carpinus, and Fagus, which occur in local flora of Lublin and the Roztocze region. The objective of this work was to find if during the study period the changes of pollen concentrations of the mentioned tree taxa were similar in two study areas located $120 \mathrm{~km}$ apart. Three methods were used to determine pollen concentration on a surface unit or in a specified volume of the air.

\section{MATERIALS AND METHODS}

As a part of the PMP, the monitoring of Alnus, Betula, Carpinus, and Fagus pollen deposition near Guciów village, in the protection zone of the Roztocze National Park, was carried out in the years 1998-2004. The PMP method consists in trapping 
of plant pollen into standard Tauber traps (Tauber, 1974; Hicks \& Hyväri $\mathrm{n}$ e $\mathrm{n}, 1986$ ), then in laboratory treatment of pollen material with the use of Lycopodium indicator tablets, and in microscopic analysis (H i c k s et al., 1996; 1999). This method enables the calculation of pollen influx, i.e. the number of pollen grains of a given taxon deposited on $1 \mathrm{~cm}^{2}$ of area in a given year.

In the first stage of fieldwork the traps are put in the ground so that only their openings are on the ground surface. The trap is a plastic container with the opening $5 \mathrm{~cm}$ in diameter, covered with wire net of large mesh. The trap bottom is covered with viscous fluid, which is a mixture of glycerine, formalin (preservative), and thymol (fungicide). Each trap rests in the ground for the whole calendar year since the October, i.e. the end of the pollen season, till the October of the next year.

The laboratory treatment of the pollen trap content consists in adding of five indicator tablets with Lycopodium spores (S to c k mar r, 1971), filtration with the use of vacuum pump, and standard Erdtman's acetolysis. During the next stage, i.e. microscopic analysis, the number of pollen grains of a given taxon is calculated in relation to the number of indicator spores. The counted sum of tree and shrub pollen (AP) is at least 500 grains, and that of Lycopodium spores 100 grains. Then the pollen influx in a given year is calculated according to the following formula:

Pollen influx $=[($ number of added Lycopodium spores / number of counted Lycopodium spores) $\mathrm{x}$ number of counted pollen grains of a given taxon] / surface area of the trap opening.

The results obtained for four traps of extralocal significance were compared. Two of them (No 6 and 7) are the so-called regional traps, i.e. placed in open communities, in plough lands or wastelands. Their contents represent regional pollen deposition, typical of a larger area. Two other traps (No 4 and 8) are placed in the large forest clearings about $80-100 \mathrm{~m}$ in diameter. They also collect extralocal pollen deposition. The results obtained for the rest of traps were not taken into account because they are placed in smaller clearings and their contents represent mostly local vegetation.

In some years it happened that the traps were destroyed or stolen in some sites and we had no results from them. And thus, in 1998 only two traps (No 4 and 6) survived, so the mean values of pollen deposition were calculated on the basis of only two results. This fact could have influenced the error of calculations. In 2000 none of regional traps (No 6 and 7) survived, so the pollen production was estimated only from the results obtained for two traps (No 4 and 8) in forest clearings, while in 2001 there was a lack of data for the trap No 8 .

In the years 1998-2000 the pollen deposition in Lublin was monitored by means of the gravimetric method with the use of Durham sampler, which was placed at a height of $9 \mathrm{~m}$ in the Stawinek quarter. Samples were taken twice a week. Annual pollen sums of Alnus, Betula, Carpinus and Fagus were calculated, and expressed as the number of grains for $1 \mathrm{~cm}^{2}$. In the years 2001-2004 the measurements were taken by volumetric method with the use of Lanzoni sampler, which was placed at a height 
of $18 \mathrm{~m}$ in the Śródmieście quarter. Annual pollen sums of the mentioned tree taxa were expressed as the number of grains in $1 \mathrm{~m}^{3}$ of atmospheric air.

Location of the study area is presented in Fig. 1.

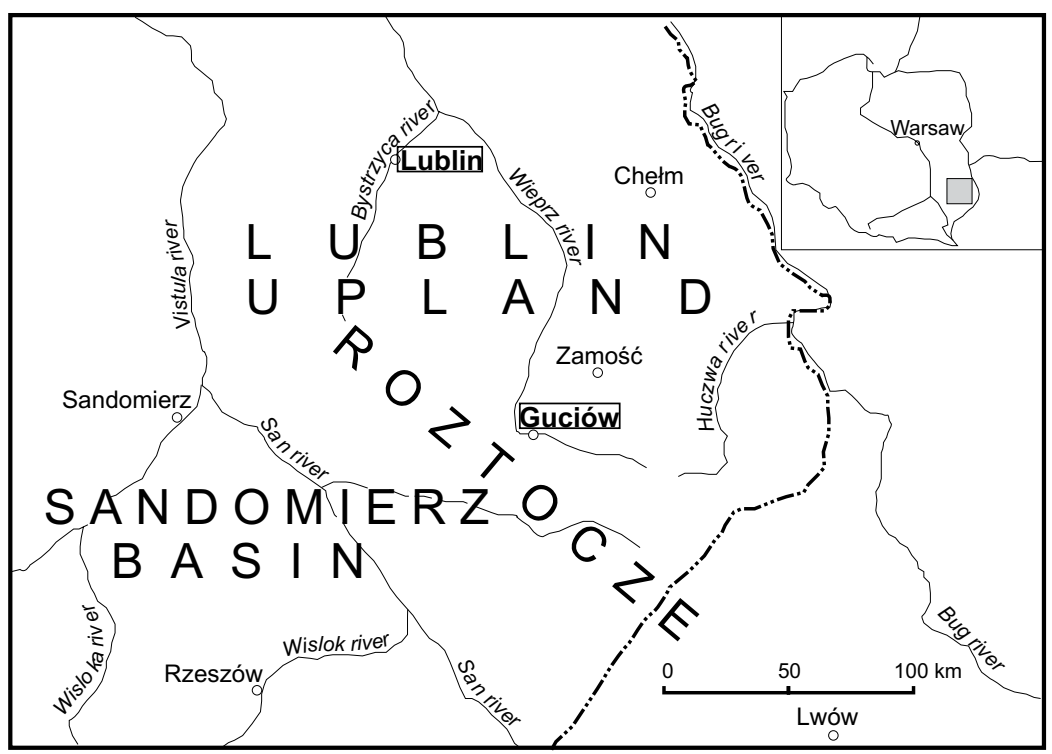

Fig. 1. Location of the study area.

In order to compare annual pollen deposition and airborne pollen concentration of each taxon, the percentage pollen index (PI) was calculated from the data obtained by means of three methods: PMP, gravimetric (with the use of Durham sampler), and volumetric (with the use of Lanzoni sampler). The calculations were done separately for three years (1998-2000) when the gravimetric method was used in Lublin, and separately for four years (2001-2004) when the volumetric method was practiced. The percentage pollen index (PI) was calculated according to the following formula:

PI = annual pollen sum in a given year / sum of pollen grains in three years' period (gravimetric method) or in four years' period (volumetric method).

In the PMP method the annual pollen sum was the average sum of pollen grains deposited per $1 \mathrm{~cm}^{2}$, calculated from the sums obtained in the four monitoring sites (except for 1998 and 2000 years, when the calculations were based on two monitoring sites only). 
Table 1

Pollen sums and PI values for selected tree taxa in Lublin and Roztocze in the period 19982004.

\begin{tabular}{|c|c|c|c|c|c|c|c|}
\hline $\begin{array}{l}\text { Taxon } \\
\text { name }\end{array}$ & Year & $\begin{array}{c}\text { Lublin } \\
\text { - annual } \\
\text { pollen sum }\end{array}$ & $\begin{array}{l}\text { Total sum (S) } \\
\text { for } 3 \text { or } 4 \text { years }\end{array}$ & PI value & $\begin{array}{c}\text { Roztocze } \\
\text { - annual } \\
\text { pollen sum }\end{array}$ & $\begin{array}{l}\text { Total sum (S) } \\
\text { for } 3 \text { or } 4 \text { years }\end{array}$ & PI value \\
\hline \multirow[t]{7}{*}{ Alnus } & 1998 & 1329 & $\mathrm{~S}=3423$ & $38.80 \%$ & 5374 & $\mathrm{~S}=6259.8$ & $85.80 \%$ \\
\hline & 1999 & 390 & & $11.40 \%$ & 661.3 & & $10.60 \%$ \\
\hline & 2000 & 1704 & & $49.80 \%$ & 224.5 & & $3.60 \%$ \\
\hline & 2001 & 6216 & $\mathrm{~S}=21617$ & $28.80 \%$ & 2836.3 & $\mathrm{~S}=7700.8$ & $36.80 \%$ \\
\hline & 2002 & 2545 & & $11.80 \%$ & 1372 & & $17.80 \%$ \\
\hline & 2003 & 7095 & & $32.80 \%$ & 2323.5 & & $30.20 \%$ \\
\hline & 2004 & 5761 & & $26.60 \%$ & 1169 & & $15.20 \%$ \\
\hline \multirow[t]{7}{*}{ Betula } & 1998 & 1284 & $\mathrm{~S}=13455$ & $9.50 \%$ & 3380.5 & $\mathrm{~S}=10061.8$ & $33.60 \%$ \\
\hline & 1999 & 3057 & & $22.70 \%$ & 2962.3 & & $29.40 \%$ \\
\hline & 2000 & 9114 & & $67.70 \%$ & 3719 & & $37.00 \%$ \\
\hline & 2001 & 13670 & $\mathrm{~S}=65805$ & $20.80 \%$ & 7458 & $\mathrm{~S}=202883$ & $2550 \%$ \\
\hline & 2002 & 5354 & & $8.10 \%$ & 2692.5 & & $9.20 \%$ \\
\hline & 2003 & 34134 & & $51.90 \%$ & 15438.5 & & $52.70 \%$ \\
\hline & 2004 & 12647 & & $19.20 \%$ & 3699.3 & & $12.60 \%$ \\
\hline \multirow{7}{*}{ Carpinus } & 1998 & 229 & $\mathrm{~S}=739$ & $3100 \%$ & 1457.5 & $\mathrm{~S}=4553.3$ & $3200 \%$ \\
\hline & 1999 & 110 & & $14.90 \%$ & 416.8 & & $9.20 \%$ \\
\hline & 2000 & 400 & & $54.10 \%$ & 2679 & & $58.80 \%$ \\
\hline & 2001 & 661 & $\mathrm{~S}=2821$ & $23.40 \%$ & 645 & $\mathrm{~S}=48383$ & $13.30 \%$ \\
\hline & 2002 & 1370 & & $48.60 \%$ & 2960 & & $61.20 \%$ \\
\hline & 2003 & 466 & & $16.50 \%$ & 780 & & $16.10 \%$ \\
\hline & 2004 & 324 & & $11.50 \%$ & 453.3 & & $9.40 \%$ \\
\hline \multirow{7}{*}{ Fagus } & 1998 & 10 & $S=70$ & $1430 \%$ & 378.5 & $\mathrm{~S}=32925$ & $1150 \%$ \\
\hline & 1999 & 7 & & $10.00 \%$ & 209 & & $6.30 \%$ \\
\hline & 2000 & 53 & & $75.50 \%$ & 2705 & & $82.20 \%$ \\
\hline & 2001 & 57 & $\mathrm{~S}=524$ & $10.90 \%$ & 104.7 & $\mathrm{~S}=4112.8$ & $2.60 \%$ \\
\hline & 2002 & 124 & & $23.60 \%$ & 1355.8 & & $33.00 \%$ \\
\hline & 2003 & 310 & & $59.20 \%$ & 2009 & & $48.80 \%$ \\
\hline & 2004 & 33 & & $6.30 \%$ & 643.3 & & $15.60 \%$ \\
\hline
\end{tabular}

Lublin, situated in the Lublin Upland (Fig.1), and neighbouring it the Roztocze region differ somewhat in respect of climatic conditions. The climate of the Lublin region is under the influence of continental air masses. Vegetation season lasts here ca.215 days (Woś, 1999). Mean yearly air temperature calculated in the period 


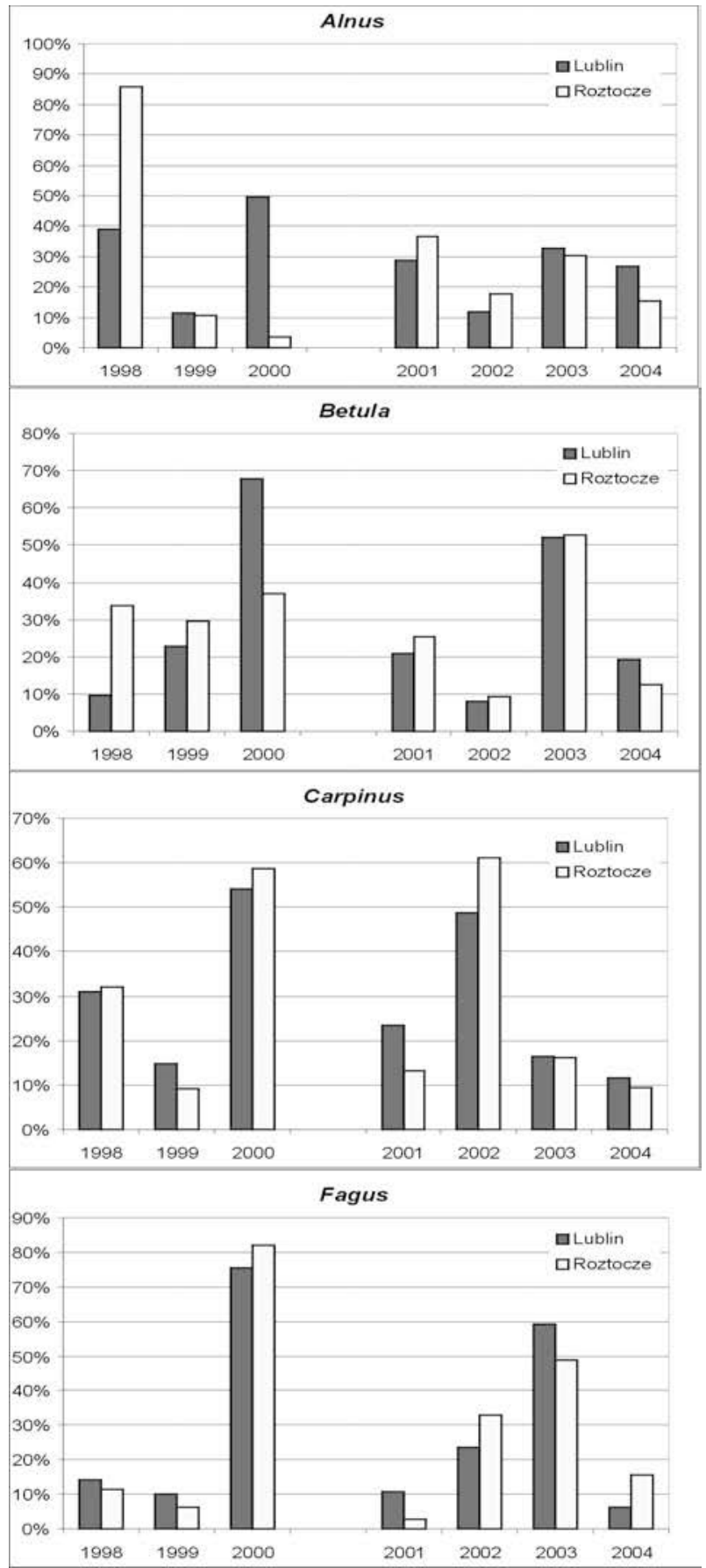

Fig. 2. PI values for Alnus, Betula, Carpinus and Fagus in Lublin and Roztocze in the period 19982004. 
$1951-1990$ is $7.4^{\circ} \mathrm{C}$. January is the coldest month with the mean temperature $3.8^{\circ} \mathrm{C}$, and July is the warmest month with the mean temperature $17.8^{\circ} \mathrm{C}$. Average yearly rainfall sum in Lublin (1951-1990) reaches $550 \mathrm{~mm}$ (K a s ze w s ki et al., 1995).

On the background of the climate of Poland, the Roztocze climate differs from other regions by the greater inflow of solar insolation especially during late summer and early autumn. Besides, yearly sums of rainfall are higher and near Guciów they reach as much as $650 \mathrm{~mm}$. Mean air temperature in January is $4.3^{\circ} \mathrm{C}$ and in July $17.7^{\circ} \mathrm{C}$. An unfavourable feature is quite great number of days with frost when the maximum daily temperature is below $0^{\circ} \mathrm{C}$. Such days occur even in May, especially in valley bottoms (K a s zew s ki et al., 2002).

\section{RESULTS AND DISCUSSION}

The analyses showed that Betula discharged the greatest amount of pollen from among four taxa in the studied areas. Annual pollen sum of Alnus is several times smaller. The comparison of annual pollen sum totals for four years (2001-2004), when in Lublin the volumetric method was used, revealed that the number of pollen grains of Betula was 3 and 3.8 times greater than that of Alnus in Lublin and in the Roztocze, respectively. Carpinus and Fagus discharged many times smaller amount of pollen than Betula (Table 1).

Similar trends were found in Lublin and in the Roztocze region as to the pollen concentrations of mentioned four taxa in particular years of the research period. It is illustrated by the percentage pollen index (PI) calculated for individual years in the two study areas. In both areas, the obtained values of PI were very similar (Table 1). The PI values for Alnus were similar in 1999 and 2003, for Betula in the 2001-2003 period and those for Carpinus in the years 1998, 2000, 2003 and 2004. Somewhat greater differences concerned the PI values of Fagus found in particular years in both areas, but still the trends in the values of pollen concentration of this taxon are identical. The only exception from this rule is the reverse tendency shown by Alnus and Betula pollen in 1998 and 2000.

In the years 1998-2000 the gravimetric method was used in Lublin, and the PMP method (basing also on gravimetric one) in the Roztocze region. In these years, a great similarity of the annual pollen sums was obtained with respect to Carpinus and Fagus. The differences did not exceed 5\% except for 2000 year when the annual pollen sum for Fagus made up for $75.5 \%$ and $82.2 \%$ of the total sum based on the three year calculations in Lublin and in the Roztocze region, respectively.

In 1999 the great similarity occurred in PI values also for Betula and Alnus (Table 1, Fig. 2). The differences did not exceed 1\%. However, in 1998 the pollen indices of both taxa were much higher in the Roztocze region, while in 2000 in Lublin. Such discrepancy in the results, exceeding several tens percent, may be caused, among other things, by the lack of data from the two damaged traps in each of these years. 
However, when volumetric method was used in Lublin, i.e. in the years 20012004, greater similarity was found with respect of annual pollen sums of all four analyzed taxa in both areas (Table 1, Fig. 2). The differences in PI values oscillate from 0.4 to $12.6 \%$. This fact can indicate greater accuracy of the results obtained with the use of the volumetric method. It should be also stressed that the data series is more complete (one season more). The only lack of data concerns the trap no 8 in 2001. The best conformity between the results occurred with reference to Alnus and Betula, while differences ca. 10\% were noted when PI values for Carpinus and Fagus were compared. Nevertheless, the differences in annual pollen sums calculated for hornbeam and beech in Lublin and in the Roztocze region are considered to be small. They can result from different participation of these two trees in vegetation cover of the studied areas. Carpinus and Fagus trees are more frequent in the Roztocze region (Z a ją c \& Z a ją c , 2001) where Fagus sylvatica forms almost single-species stands of the Carpathian beech wood. Its eastern tree line runs across the Roztocze region (S zw e y k ow s ka \& S zwe y k ow s k i, 1993). Carpinus betulus occurring frequently in forest borders in the Roztocze region produces more pollen and fruits than the specimens growing in dense forest due to sufficient insolation ( $\mathrm{S} \mathrm{u} \mathrm{s} \mathrm{z} \mathrm{k} \mathrm{a} \mathrm{,} \mathrm{1993).}$

With respect of Betula, biannual cycle of abundant pollen production was found earlier by several authors (S p i e k s m a et al., 1995; C ord e n et al., 2000; L a t a $ł$ ow a et al., 2002). Higher concentrations of Betula and Alnus pollen were recorded both in Lublin and in the Roztocze region in some years (for example 2001 and 2003).

The cycles of pollen deposition were more difficult to determine with respect of taxa discharging a smaller amount of pollen, to which Carpinus and Fagus belong. However, the years of high pollen concentration were found for each of them during the seven-year period. In the case of Carpinus, it was 2002 year, both in Lublin and in the Roztocze region. The highest concentrations of Fagus pollen were recorded in 2000 and 2003 (Table 1). Worthy noticing is also quite great similarity of PI values obtained for Fagus in both areas, in spite of its much more numerous occurrence in the Roztocze.

The intensified tree pollen concentration in some years can be favoured by weather conditions, in it insolation (S p i e k s m a et al., 2003), and by the features associated with biology of tree development, i.e. alternating production of large assimilation surface of leaves and high number of inflorescences in successive years (Dahl \& Strandhede, 1996). In the opinion of other authors (Hicks et al., 1994), high pollen production resulting in rich fruiting needs much energy in a given year, and causes development inhibition of flowers in next year. Moreover, abundant beech pollen production seems to depend on higher than average July temperature of the previous year when pollen grains begin to form in the inflorescences $(\mathrm{C} \mathrm{h}$ a $1 \mathrm{u} \mathrm{p}$ $\mathrm{k} \mathrm{a}, 1990)$.

To sum up, during seven years of studies we recorded rather great similarity of the obtained results in two areas with slightly different climatic conditions, and very different vegetation cover, located $120 \mathrm{~km}$ apart. The applied methods were also different. Despite these differences, the recorded similar trends in pollen values (PI) indicate the occurrence of regional factors, which influence the production of pollen by trees of the examined taxa. 


\section{REFERENCES}

B roströ m A., 2002. Estimating source area of pollen and pollen productivity in the cultural landscapes of southern Sweden developing a palynological tool for quantifying past plant cover. LUNDQUA Thesis 46. Lund University, pp. 42.

Ch a ł u p k a W., 1990. Wybrane zagadnienia rozwojowe i wzrostowe. [in:] S. Białobok (ed.). Buk zwyczajny (Fagus sylvatica L.). Nasze drzewa leśne 10. PWN, Warszawa Poznań; 123141.

Corden J., Millington W., Bailey J., B rookes M., Caulton E., Emberlin J., Mullins J., Simpson C., Wood A., 2000. UK regional variations in Betula pollen (1993 1997). Aerobiologia, 16: 227232.

Dahl A., Strandhede S. O., 1996. Predicting the intensity of the birch pollen season. Aerobiologia, 12: 97106.

D u r h a m O. C., 1964. Proposal standard metod of gravity sampling. J. Allergy, 30: 6770.

H i c k s S., H y v ä r i n e n V. P., 1986. Sampling modern pollen deposition by means of Tauber traps: some considerations. Pollen et Spores, 28; 219242.

Hi ck s S., Hel a n d e r M., He in o S., 1994. Birch pollen production, transport and deposi tion for the period 19841993 at Kevo, northernmost Finland. Aerobiologia, 10: 183191.

Hicks S., Ammann B., Latał ow a M., Pardoe H., Tinsley H., 1996. European Pollen Monitoring Programme. Project Description and Guidelines. Oulu Univ. Press, Oulu, Finland, 28 pp.

Hicks S., Tinsley H., Pardoe H., Cundill P., 1999. European Pollen Monitoring Programme. Supplement to the Guidelines. Oulu Univ. Press, Oulu, Finland, 24 pp.

Hirst J. M., 1952. An automatic volumetric spore trap. Ann. Appl. Biol. 39: 257265.

Käp y lä M., Penttinen A., 1981. An evaluation of the microscopical counting methods of the tape in Hist. Burkard pollen and spore trap. Grana, 20: 131141.

Ka s ze w ski B. M., Mrug ał a S., Warak o m ski W., 1995. Klimat. Temperatura powie trza i opady atmosferyczne na obszarze Lubelszczyzny (1951 1990), Lubelskie Towarzy stwo Naukowe: Lublin.

Ka s zew ski B. M., C zerniawski M., Mucha B., 2002. Warunki klimatyczne Rozto cza. [in:] J. Buraczyński (ed.) Roztocze środowisko przyrodnicze. Wyd. Lubelskie, Lublin; 208220.

Latałowa M., Miętus M., Uruska A., 2002. Seasonal variation in the atmospheric Betula pollen count in Gdańsk (southern Baltic coast) in relation to meteorological parame ters. Aerobiologia, 18: 3343.

Mandrioli P., Comtois P., Domininquez Vilches E., Galan Soldevilla C., S y z d e k L., I s a r d S., 1998. Sampling: principles and techniques. [In]: P. Man drioli, P. Comtois, V. Levizzani (eds), Methods in aerobiology. Pitagora Editrice Bologna: 47112.

R a y n or G. S., 1979. Sampling techniques. Aerobiology. The Ecological System Approach US/IBP Synthesis series, 10: 151169.

S pieksma F. Th. M., Emberlin J. C., Hjelmroos M., Jäger S., Leuschner R. M., 1995. Atmospheric birch (Betula) pollen in Europe: trends and fluctuations in annual quantities and the starting dates of the season. Grana, 34: 5161.

Spieksma F. Th. M., Corden J. M., Detandt M., Millington W. M., Nikkels H., Nolard N., Schoenmakers C. H. H., Wachter R., de Weger L. A., W i 11 e m s R., E m b e r l i n J., 2003. Quantitative trends in annual totals of five common airborne pollen types (Betula, Quercus, Poaceae, Urtica and Artemisia), at five pollen monitoring stations in western Europe. Aerobiologia, 19: 171184. 
S t o c k m a r r J., 1971. Tablets with spores used in absolute pollen analysis. Pollen et Spores, 13; 615621.

S u s z k a B., 1993. Rozmnażanie generatywne. [In:] W. Bugała (ed.). Grab zwyczajny (Carpi nus betulus L.). Nasze drzewa leśne, 9. Wyd. Sorus, Poznań Kórnik: 97134.

S z we y k ow sk a A., S z we y k ow s ki J., 1993. Słownik botaniczny. Wiedza Powszechna, Warszawa.

Ta u b e r H., 1974. Investigations of aerial pollen transport in forested area. Dansk Botanisk. Arkiv, 32; 1121.

Woś A., 1999. Klimat Polski. Wyd. Naukowe PWN, Warszawa.

$\mathrm{Z}$ a ją c A., Z a j ą c M. (eds.), 2001. Distribution Atlas of Vascular Plants in Poland. Pracownia Chorologii Komputerowej Instytutu Botaniki Uniwersytetu Jagiellońskiego, Kraków.

\title{
Porównanie koncentracji ziarn pyłku wybranych taksonów drzew w Lublinie i na Roztoczu przy zastosowaniu trzech metod badań
}

\begin{abstract}
Streszczenie
Wiatropylne drzewa z rodzaju Betula i Alnus produkują bardzo duże ilości łatwo rozprzestrzeniającego się pyłku. Mniej ziarn pyłku uwalniają do atmosfery Carpinus i Fagus. Drzewa należące do wymienionych rodzajów są reprezentowane w roślinności Lublina i na Roztoczu, gdzie przeprowadzono badania porównawcze. Celem badań było określenie koncentracji pyłku czterech taksonów drzew w latach 1998-2004 w dwóch punktach pomiarowych, oddalonych od siebie o 120 km. Porównywano roczne sumy ziarn pyłku uzyskane przy zastosowaniu trzech metod, aby ustalić stopień zgodności w zakresie przemiennie występującego u drzew obfitego i słabego pylenia w poszczególnych latach. Na Roztoczu badania prowadzono w ciągu siedmiu wymienionych lat w ramach Pollen Monitoring Programme, który zmierza do dostarczenia wieloletnich danych wykorzystywanych do rekonstrukcji paleoekologicznych czwartorzędu oraz do interpretacji o charakterze fenologicznoklimatycznym. Stosowano tu standardowe pułapki pyłkowe typu Taubera. W Lublinie w latach 1999-2000 prowadzono badania metodą grawimetryczną, zaś w latach 2001-2004 metodą wolumetryczną. Stwierdzono, że w Lublinie i na Roztoczu zaznaczyły się podobne tendencje w zakresie zawartości ziarn pyłku w powietrzu wymienionych taksonów w poszczególnych latach badań. Betula i Alnus uwalniały największe liczby ziarn pyłku. W roku 1999 przy stosowaniu metody grawimetrycznej, we wszystkich punktach pomiarowych wykazano dużą zbieżność wyników dotyczących wysokości sum rocznych ziarn pyłku dla trzech taksonów. Wyjątek stanowił Carpinus, u którego produkcja pyłku była znacznie większa na Roztoczu niż w Lublinie. W przypadku Carpinus wzmożoną produkcję pyłku notowano w obu punktach badawczych w 2002 roku, zaś pyłek Fagus pojawił się najobficiej w roku 2002 i 2003. W ciągu kilku lat badań zarejestrowano dużą zgodność uzyskanych wyników w znacznie oddalonych od siebie punktach badawczych.
\end{abstract}

